\title{
Issue Salience in the U.S. Elections: "Partisan Domestication" between South Korean Newspapers
}

\author{
Jae Sik Ha ${ }^{1}$, Uche Onyebadi ${ }^{2}$, Dong-Hee Shin ${ }^{3}$ \\ ${ }^{1}$ Communication Department, University of Illinois at Springfield, USA \\ ${ }^{2}$ Department of Journalism, Texas Christian University, USA \\ ${ }^{3}$ School of Media and Communication, Chung-Ang University, Seoul, Korea \\ Correspondence: Dong-Hee Shin, School of Media and Communication, Chung-Ang University, Seoul, Korea.
}

Received: August 1, 2017

doi:10.11114/smc.v5i2.2689
Accepted: September 29, 2017

Online Published: October 9, 2017

URL: https://doi.org/10.11114/smc.v5i2.2689

\begin{abstract}
This study examines how two newspapers in South Korea, one conservative and one liberal, covered the U.S. presidential election of 2008. The study found that there was a significant divergence in the emphasis placed on certain types of issues between the two ideologically polarized newspapers. While the liberal Hankyoreh Daily placed more emphasis on social justice issues - such as racial equality and the abolition of social discrimination, the conservative Chosun Daily highlighted "human interest" issues, focusing on more trivial topics such as the candidates' gender, family, and fashion preferences. There was also a difference in the types of news sources used by the two newspapers. The Hankyoreh Daily sought to represent the voices of the South Korean elite, while The Chosun Daily used American politicians as one of its major source of information. This study argues that a news organization's ideological orientation is an important factor, which influences South Korean newspapers' "domestication" of the U.S. election, which was staged in a distant region.
\end{abstract}

Keywords: agenda-setting, journalism, newspaper, partisan media, South Korea, U.S. election

\section{Introduction}

The U.S. presidential election of 2008 attracted international attention primarily because the U.S. enjoys a preeminent position in world politics as a result of its military and economic power. BBC broadcaster Dotun Adebayo (2008), while commenting on the global significance of the presidential contest on the U.S. National Public Radio (NPR) News \& Notes program, argued that the U.S. election had international consequences because "whoever has the keys to Pennsylvania Avenue [i.e., the White House] is going to dominate world politics for... the next four years or so."

For South Koreans, the outcome of the U.S. presidential election had crucial foreign policy and national security implications as a result of the opposing views held by the candidates on two issues of national importance for South Korea: the South Korea-U.S. Free Trade Agreement (FTA) and South Korea-North Korea relations.

During the campaign, candidate Obama called for the FTA to be renegotiated, insisting that "the accord does not do enough to address concerns of American autoworkers" (2008, June 4). In contrast, McCain (2008) argued, "we have negotiated a trade agreement with South Korea that will expand American exports and create American jobs."

On the relationship between North and South Korea, Obama adopted a somewhat conciliatory approach, asserting that "we must work with diligence and determination with our friends and allies to end this dangerous threat and to secure a lasting peace on the Korean peninsula" (Ellis, 2008, June 26). McCain was more belligerent toward North Korea, advocating that the U.S. should mobilize international opinion against the abuses of human rights in that country, rather than embrace its leader, Kim Jong-il (Mason, 2008, April 24).

The U.S. and South Korea have been strongly allied since the Korean War of 1950-53. Given the importance of the South Korea-North Korea relations, the FTA, and other issues, this study examines the differences and similarities in the coverage of the U.S. presidential election of 2008 by two prominent newspapers in South Korea-The Chosun Daily and The Hankyoreh Daily. It also explores in what ways local journalists' selection of news sources influenced their choices of the salient issues in this important news event. 
The Chosun Daily and The Hankyoreh Daily were chosen because of their contrasting ideological approaches. The Chosun Daily is regarded as one of the most conservative dailies in South Korea, while The Hankyoreh Daily, a prominent liberal paper, has generally advocated progressive values in its coverage of public issues. Thus, not only does this study investigate how these two news outlets' evident partisanship colored their reporting of a global news event, but it seeks to explore in what ways the ideological orientations of news outlets in general can serve as an important variable which shapes the international agenda-building process.

One of the common criticisms of the coverage of elections is that the news media have tended to portray politics as a kind of game played among political factions by putting an emphasis on political strategies and tactics while undervaluing real policy issues (Dimitrova \& Stromback, 2011; Cappella \& Jamieson, 1997; Patterson, 1993). It is in this context that the present study examined the extent to which The Chosun Daily and The Hankyoreh Daily paid attention to major issues, including both the "horse-race" issues and the "substantive" public issues (policy aspects of the race). The "horse race" issues largely concern the candidates' performance at the polls. In contrast, the "substantive public issues" refers to public policy agendas, such as those, which concern the economy or foreign affairs. In the end, this study seeks to investigate not only how distinctive the two liberal and conservative papers were in both their presentation of issues and their usage of news sources, but also how the choice of news sources determined the South Korean media's agendas in their coverage of the U.S. election.

\subsection{Significance of the Study}

This study employed an agenda-setting theory in its examination of the issues that the editors of South Korean print media considered appropriate and newsworthy. Issues, when emphasized by the news media, tend to facilitate the formation of the social reality and worldview of the media's audience (Shoemaker \& Vos, 2009). Agenda setting theory postulates that those issues which are chosen to be highlighted by the news media eventually become what their audiences consider to be the most important issues of the day (McCombs \& Shaw, 1972; McCombs, 2004; Weaver, 2007). Thus, this study can enhance the scope of journalism research by providing some insight into the under-researched area of how the U.S. presidential election, an evidently important international news event, was presented to their local audiences by two major print publications from opposing sides of the political spectrum in South Korea.

Consequently, this study attempts to deepen our understanding of how the newsworthiness of an issue is influenced by a range of factors, such as a news organizations' partisanship, access to sources, and the political climate with respect to international relations. There have not been sufficient studies on how news organizations' ideological orientations influence their coverage of foreign news events, and South Korea is a country where ideological polarization among the mainstream news media is particularly intense (Lee, 2006).

Thus, this study can provide an opportunity to examine how the coverage and "domestication" of the U.S. election event by Korean news media can be influenced by those news organizations' partisanship. A number of studies-such as those published by Galtung and Ruge (1965), Ostgaard (1965), Hester (1973), Scammell (2005), and Golan (2006) - have examined the various factors that affect international news coverage by domestic media.

International news, when delivered to a domestic audience, tends to be an "out there" or "foreign" phenomenon, which means that local journalists are constrained to publish only those news items that are meaningful to their local audiences. It is in this context that this study seeks to advance the concept of the sociology of news by exploring which news sources were given more prominence by South Korean journalists and in what ways those news sources influenced the salience of issues in the case of South Korean newspapers' coverage of the U.S. election.

\subsection{Newsworthiness}

Journalists are continuously engaged in the process of determining what news is worthy for publication. Despite this recurring editorial task, the reasons why journalists select some news items for publication and discard others remains enigmatic (Reinemann \& Shulz, 2006; Schwarz, 2006). The components of "news value" include "sensationalism, proximity, relevance, unambiguity, and facticity" (Eilders, 2006). Shoemaker and Reese (2013) proposed the following elements of news value: timeliness, novelty, proximity to audiences, and controversy or conflict. National interest is also considered an important criterion in determining "news value" (Dimitrova, et al., 2005; Kim, 2002). All of these are also influenced by the journalists' professional and newsroom routines as well as by organizational imperatives (Shoemaker \& Reese, 2013; Graber, 2010).

Given the position of the U.S. as a superpower with global political and economic clout, the outcome of its presidential election is bound to be of interest to many nations. Furthermore, the 2008 U.S. election represented a new era in U.S. presidential history since candidate Barack Obama was not just the first serious African American contender, but also the frontrunner during the election. In other words, the election was worthy of coverage as an important event. On the 
other hand, the political and economic ties between the U.S. and South Korea provided context to the coverage by the media. South Korea is a strategic ally of the U.S. in Asia, and the two major issues of concern to both nations at that time were their bilateral FTA and their foreign policies toward North Korea. It is possible that South Korean newspapers would pay attention to the 2008 presidential polls not only because of the close ties between South Korea and the U.S. in areas such as trade and foreign policy, but also because of the nature of the U.S. presidential election as a major international event.

\subsection{Agenda-Setting and Issue Salience}

Lippmann (1922) stated that the pictures formed in people's heads are inherently incomplete and distorted reality of the external world, since the media intrinsically display only a very narrow part of the world to their audience. Many scholars have proposed that the content of the news is not at all a reproduction of an objective reality, but should be considered as a result of the interactions between journalists, power elites, news sources, and citizens and is also strikingly affected by the political ideologies and social institutions within a society (Guzman, 2016; Croteau \& Hoynes, 2003; Graber, 2010; Patterson, 1993, 2000; Shoemaker \& Reese, 2013; Tuchman, 1978).

Agenda setting theory proposes that, since the news media is able to place greater emphasis on some issues over others, the salience assigned to those issues can be transmitted from the media to the public (McCombs \& Shaw, 1972; McCombs \& Shaw, 1993). Due to the transmission of issue (object) salience, the news media are able to play an important role in influencing the public's opinions (Weaver, 2007; Takeshita, 1997).

When journalists present an issue to their audiences, they tend to highlight certain issues while de-emphasizing others. According to the agenda-setting perspective, news items or issues, presented by the news media, engage the media's audiences and leave them with a sense of knowing what the important issues of the day are about. In this way, journalists and the news media become agenda setters for their audiences. In particular, the news coverage of an international event is also susceptible to the agenda-setting process.

In particular, since citizens are generally restricted in their direct experiences of international events, journalists or editors in local media are able to exercise more power and authority to shape the public's views of international issues in their preferred ways. Thus, the "domestication of news" -the ways in which news media largely reflect their country's national interests and cultural stereotypes in their coverage (Hafez, 2007)- may be seen to be frequently manifested in the reporting of international issues.

\section{4 "Horse-Race" Coverage}

Previous research has shown that, in political elections, it is the "horse-race" aspect of campaigns, which tends to dominate media reporting (Asher, 2007; Patterson, 2005; Mann \& Orren, 1992; Holley, 1991). "Horse race" coverage essentially refers to that which primarily (or even exclusively) emphasizes what the polls show regarding which candidate might be ahead or behind in a race for political office at any given moment in time. The predominance of such horse-race coverage is partly attributable to voters' eagerness to know how the candidates stand relative to each other in their campaign for elected office (Iyengar et al., 2004).

However, Kovach (1980) observed that the media's overemphasis on horse-race matters, often results in potentially serious candidates, even those with credible agendas, being forced to quit early in a political race simply because they are seen as not doing well in the polls. Fahey (2007) claimed that horse-race coverage is convenient to less diligent reporters and media organizations, due to their tendency to avoid the rigors of "serious analysis, critique, or challenging commentary" during coverage of political elections (p. 136). Horse-race level reporting focuses on "competition for competition's sake" (Bartels, 1988, p. 31) and, by putting enormous emphasis on one aspect of an election, a news outlet simply "reduces election coverage to a simple win-lose situation" (Gan, Teo, \& \& Detenber, 2005, p. 448).

Despite these criticisms, some scholars, most notably Ladd and Benson (1992) and Broh (1980), have underscored the necessity for horse-race reporting, asserting that it allows voters to learn about public issues and the character of candidates for political office. Zhao and Bleske (1998) have further argued that horse-race reporting enhances voters' learning of issues during elections as well as their understanding of public policy.

The horse-race coverage of election is indeed not new to South Korean media. Kim and Kwon (2009) observed that South Korean media have focused on horse-race issues in a number of South Korean presidential elections, and South Korean TV networks have covered U.S. presidential elections in the way they cover real horse races. For example, Lee and Lee (2004) contended that TV networks in South Korea concentrated on sensation-oriented horse-race reporting in their coverage of the 2004 U.S. presidential election by giving virtual day-to-day updates on what the polls said about the candidates' chances in the election. 


\subsection{Research Question and Hypothesis}

The national interest of any medium's home country is one of the major factors, which influences media coverage when news media and their journalists cover international issues (Lee \& Yang, 1995; Lee et al, 2005; Novais, 2007). Thus, given that the 2008 U.S. election was crucial to the national interests of South Korea, it was not surprising that South Korean journalists would also consider both the FTA between the U.S. and South Korea and U.S. policy towards North Korea to be important issues, which were very relevant to their nation and its people.

In South Korea, conservative media are generally inclined to support the FTA due to their positive views toward the U.S. as an ally. In contrast, the liberal media are somewhat critical of the trade agreement with the U.S. due to the perception that it could infringe on the sovereignty of South Korea. Regarding the relationship with North Korea, the liberal media generally take a conciliatory attitude toward North Korea while the conservative media advocate tougher policies towards their neighbor to the north. Thus, given the different ideological orientations frequently expressed by both newspapers, it is important to assess how often the conservative Chosun Daily and the liberal Hankyoreh Daily reported both of these national interest issues in their coverage of the U.S. election. Therefore, this study poses the following research question:

RQ1: How did the conservative Chosun Daily and the liberal Hankyoreh Daily differ in their coverage of the most important issues relevant to Korea's national interest (i.e., the FTA and relations with North Korea)?

The literature on the coverage of political elections shows that the media tend to pay excessive attention to horse-race issues (Gan, Teo, \& Detenber, 2005). Lee and Lee (2004), as well as Kim and Kwon (2009), specifically noted the preponderance of horse-race coverage in South Korean elections. However, the ways in which the partisanship of news outlets can influence the frequency of horse-race issues over "substantive" policy issues have largely been unexplored. This study therefore poses the following research question:

RQ2: How did the conservative Chosun Daily and the liberal Hankyoreh Daily differ in their treatment of horse-race matters in their coverage of the U.S. election?

The Chosun Daily and The Hankyoreh Daily have framed news events from conservative and liberal ideological points of view, respectively. The liberal Hankyoreh Daily has been active in enhancing political democratization and in disseminating the liberal point of view in South Korean society (Han, 2000; Min, 2000; Song, 2007). It published its first issue in 1988, when 67,300 citizens came together as shareholders in the new company in order to establish an independent newspaper. In contrast, The Chosun Daily is the leader in South Korea's newspaper market, occupying about a 25\% share of the market for printed newspapers (Park, 2008, September). However, The Chosun Daily is frequently criticized as being not only too conservative and sensationalism-oriented, but also as being unresponsive to social causes including social justice (Kang, 2005; Lee et al., 2010). Thus, this study predicted that both newspapers would place different levels of emphasis on issues, namely:

H1: The Hankyoreh Daily will emphasize social justice issues (e.g., racial discrimination, advocacy for the unprivileged), while The Chosun Daily will highlight human interest issues (e.g., the candidates' clothes, family, and career).

An examination of the news sources used in each article during the 2008 presidential election published by The Chosun Daily and The Hankyoreh Daily will shed some light on how South Korean journalists construct their news stories. In addition, such an examination can also illustrate in what ways the partisanship of newspaper media may determine the selection of news sources. Thus, this study proposes the following research question:

RQ3: How did the conservative Chosun Daily and the liberal Hankyoreh Daily differ in their usage of news sources in covering the 2008 U.S. election?

\section{Method}

Data for this study were obtained from the two South Korean (language) newspapers, The Chosun Daily and The Hankyoreh Daily. The unit of analysis is a single news story which can be effective for detecting the background of an issue as well as the journalist's emphasis on, or exclusion of, certain elements. The period covered by this research was from Aug. 25, 2008 (the starting date of the Democratic National Convention) to Nov. 4, 2008 (the presidential election day).

News stories by The Chosun Daily were acquired as PDF (Portable Document Format) files from that newspaper's website; The Hankyoreh Daily's stories were retrieved from the Korean Integrated News Database Service (KINDS). In both instances, the stories were identical to those which had appeared in the print editions of the newspapers. Editorial and opinion columns were excluded since the editorial and opinion columns concerning the 2008 U.S. election in the two papers were relatively few in number and were not expected to affect the overall findings of the study. In all, 315 
news stories were obtained (The Chosun Daily, 185; The Hankyoreh Daily, 130).

Coding

Data obtained for this study were categorized into the following:

\section{(1) National Interest}

The national interest issue was coded according to whether each news story discusses issues - North Korea and the South Korea-U.S. FTA - crucial to the national interest of South Korea. There are two sub-categories in this classification: (1) National Interest stories; (2) Non-National Interest stories.

(2) Primary Issue

The primary issue in each news article was determined according to the major topic of each story. It was coded according to the following classifications: (1) Economy; (2) Foreign affairs issues (e.g., the Iraq War, the War on Terror, North Korea, diplomacy); (3) Horse-race (e.g., campaign strategy, polling results); (4) Human interest (e.g., race, gender, family, fashion, career, candidate's health); (5) Social Justice (e.g., racial discrimination or social and economic equality); (6) Qualification (morality or capability) of candidate; (7) Voting issues and the electoral system; (7) Others.

\section{(3) Source}

A "source" refers to a person or organization that is quoted or stated as a source of information in the news stories. In consideration of journalists' general tendency to cite their major sources at the beginning of their stories, the first source in each story was coded as the main source. The source-classifications were: (1) Candidates; (2) American Politicians; (3) American Scholars or Experts; (4) South Korean Elites (i.e., politicians and scholars); (5) American Media; (6) American Citizens; (7) Others.

Inter-coder reliability

Coding the stories and articles for this study was performed by one of the authors and a doctoral student in mass communications. Twelve percent of the stories were used to test for inter-coder reliability. Landis and Koch (1977) suggested that Cohen's kappa figures of between 0.61 and 0.81 would be quite sufficient for any quantitative research. The kappa figures for our statistics were: national interest (1); primary issue (.81); primary news source (.76).

\section{Results}

RQ1 examined the extent to which the conservative Chosun Daily and the liberal Hankyoreh Daily reported on the U.S. election in terms of their own country's national interest. The results presented in Table 1 show that both newspapers reported major national interest stories less frequently. The Chosun Daily devoted $8.6 \%$ of its reports to major national interest issues, while The Hankyoreh Daily reported $7.7 \%$ of its stories on those same issues. Both newspapers overwhelmingly published non-major national interest stories $(91.4 \%$ for The Chosun Daily and $92.3 \%$ for The Hankyoreh Daily). There was also no significant difference in this regard between The Chosun Daily and The Hankyoreh Daily $\left[\chi^{2}(d f=1)=.092, p=.761\right]$.

Table 1. Comparison of National Interest and Non-National Interest Issues

\begin{tabular}{lll}
\hline & Chosun Daily & Hankyoreh Daily \\
\hline National Interest & $8.6 \%(16)$ & $7.7 \%(10)$ \\
Non-National Interest & $91.4 \%(169)$ & $92.3 \%(120)$ \\
Total & $100 \%(185)$ & $100 \%(130)$ \\
\hline
\end{tabular}

$* \chi^{2}(d f=1)=.092, p=.761$

RQ2 examined the types of issues that The Chosun Daily and The Hankyoreh Daily highlighted in their coverage and predicted that horse-race matters would be the most prominently covered issues by the newspapers. Our findings in Table 2 show that the most salient issues in newspapers' news coverage of the 2008 U.S. election belonged to the horse-race category $(39.4 \%)$, while human interest $(19.0 \%)$ and social justice $(8.9 \%)$ ranked second and third. There was no significant difference in the amount of attention paid to the horse-race issue by either of the two newspapers (The Chosun Daily, $37.3 \%$; The Hankyoreh Daily, 42.3\%). These results show that the horse-race coverage displaced substantive/policy issues such as the economy and foreign affairs in the news coverage of both newspapers. Our findings show that there is no significant difference in issue salience between The Chosun Daily and The Hankyoreh Daily (rho=.038, p=.496, 2-tailed). 
Table 2. Comparison of Primary issues in South Korean Newspapers

\begin{tabular}{llll}
\hline Issues & $\begin{array}{l}\text { Chosun Daily } \\
\mathrm{N}=185\end{array}$ & $\begin{array}{l}\text { Hankyoreh Daily } \\
\mathrm{N}=130\end{array}$ & $\begin{array}{l}\text { Total } \\
\mathrm{N}=315\end{array}$ \\
\hline Horse-race & $37.3 \%(69)$ & $42.3 \%(55)$ & $39.4 \%(124)$ \\
Human Interest & $27 \%(50)$ & $7.7 \%(10)$ & $19.0 \%(60)$ \\
Social Justice & $4.3 \%(8)$ & $15.4 \%(20)$ & $8.9 \%(28)$ \\
Candidate Qualification & $8.6 \%(16)$ & $8.5 \%(11)$ & $8.6 \%(27)$ \\
Others & $5.9 \%(11)$ & $10.8 \%(14)$ & $7.9 \%(25)$ \\
Foreign Affairs & $7.6 \%(14)$ & $7.7 \%(10)$ & $7.6 \%(24)$ \\
Economy & $5.9 \%(11)$ & $6.9 \%(9)$ & $6.3 \%(20)$ \\
Election System & $3.2 \%(6)$ & $0.8 \%(1)$ & $2.2 \%(7)$ \\
\hline
\end{tabular}

$*($ rho $=.038, \mathrm{p}=.496,2$-tailed, $\mathrm{n}=8)$.

H1 predicted that, given their different ideological orientations, The Chosun Daily and The Hankyoreh Daily would respectively place their emphasis on human interest and social justice issues in their coverage. This hypothesis was supported by the data $\left(\chi^{2}(d f=2)=26.217, p<.001\right)$. Table 2 shows that The Chosun Daily presented human interest issues as being more important in its news coverage (27\%), while these issues occupied only $7.7 \%$ of The Hankyoreh Daily's coverage. In contrast, The Hankyoreh Daily placed considerable emphasis on social justice issues in its coverage of the elections (15.4\%), while the percentage of social justice issues in The Chosun Daily's coverage was a mere 4.3\%.

RQ3 examined how the conservative Chosun Daily and the liberal Hankyoreh Daily would differ in their usage of news sources in their coverage of the election. As Table 3 shows, there was indeed a significant difference between the two: $\left(\chi^{2}(d f=6)=20.36, p<.01\right)$. One finding in this regard is that though the ratio of the reliance on U.S. media as a news source (compared to other sources) was high for both newspapers, the level of dependence of The Chosun Daily (47.6\%) was slightly higher than that of The Hankyoreh Daily (41.5\%). As Table 3 indicates, The Hankyoreh Daily used three news sources-American scholars (or experts), South Korean elites, and American citizens-more frequently than did The Chosun Daily. By contrast, the candidates themselves and other American politicians were more often quoted as major sources in The Chosun Daily than in The Hankyoreh Daily.

Table 3. Comparison of News Source Type in South Korean newspapers

\begin{tabular}{lllllllll}
\hline Source & Candidate & $\begin{array}{l}\text { American } \\
\text { Politician }\end{array}$ & $\begin{array}{l}\text { American } \\
\text { Scholar } \\
\text { Expert }\end{array}$ & $\begin{array}{l}\text { South } \\
\text { or } \\
\text { Elite }\end{array}$ & $\begin{array}{l}\text { U.S. } \\
\text { media }\end{array}$ & $\begin{array}{l}\text { American } \\
\text { Citizens }\end{array}$ & Others & Total \\
\hline Chosun Daily & $24.3 \%$ & $13.5 \%$ & $5.4 \%$ & $1.1 \%$ & $47.6 \%$ & $2.7 \%$ & $5.4 \%$ & $100 \%$ \\
& $(45)$ & $(25)$ & $(10)$ & $(2)$ & $(88)$ & $(5)$ & $(10)$ & $(185)$ \\
Hankyoreh & $19.2 \%(25)$ & $8.5 \%$ & $13.1 \%$ & $8.5 \%$ & $41.5 \%$ & $5.4 \%$ & $3.8 \%$ & $100 \%$ \\
Daily & & $(11)$ & $(17)$ & $(11)$ & $(54)$ & $(7)$ & $(5)$ & $(130)$ \\
Total & $22.2 \%$ & $11.4 \%$ & $8.6 \%$ & $4.1 \%$ & $45.1 \%$ & $3.8 \%$ & $4.8 \%$ & $100 \%$ \\
& $(70)$ & $(36)$ & $(27)$ & $(13)$ & $(142)$ & $(12)$ & $(15)$ & 315 \\
\hline
\end{tabular}

$* \chi^{2}(d f=6)=20.36, p<.01$

\section{Discussion}

This study offers a good opportunity to explore in what ways the "domestication of news" was executed in South Korean newspaper media's coverage of the U.S. election. The conservative and liberal papers in South Korea differed in their emphasis of certain issues, depending upon their ideological predilection; the conservative Chosun Daily highlighted human interest issues, while the liberal Hankyoreh Daily emphasized social justice issues. These findings showed that the partisanship of news outlets could be an important factor in shaping the "issue salience" manifested in the coverage of an event like the U.S. election. In addition, the study found that, in both cases, the horse-race aspect of the coverage exceeded the coverage of substantive issues. It is likely that the South Korean newspaper media's emphasis on horse-race coverage might have been the result of the South Korean journalists' reliance on the U.S. media as their primary news sources.

\subsection{Conspicuous Horse-Race Coverage}

South Korea and the U.S. have long maintained a strong bilateral relationship dominated by economic and security issues. The Korea-U.S. FTA is the backbone of the economic relationship, while the security aspect is largely concerned 
with how to deal with South Korea's neighbor-North Korea. The importance of South Korea-U.S. relations is exemplified by the fact that that issue came up in a major foreign policy debate between candidates Obama and McCain during the 2008 campaign. The two contenders held diametrically opposed views on issues relating to South Korea. Therefore, given the fact that the presidential candidates in the U.S. made South Korea-U.S. relations a major campaign issue, it was expected that the media in South Korea would show substantial interest in covering the 2008 election, paying special attention to the twin issues of the FTA and relations with North Korea.

However, our findings show that horse-race issues were the most salient concerns found in the coverage by both newspapers. This excessive attention paid to horse-race oriented stories overshadowed coverage of the serious debates concerning South Korea-U.S. relations. Beyond the partisanship of these news outlets, both the South Korean newspaper media slanted their coverage of political elections in favor of horse-race matters over more substantial issues. It is probable that since the FTA and relations with North Korea were not prominent issues of contention in the U.S., the American media would not be actively covering these issues. This in turn may have affected the volume of coverage by both South Korean newspapers, since they largely relied on news sources from the U.S. media for their own reports on the campaign.

It is also likely that for South Korean media covering a campaign taking place in the U.S., horse-race coverage would be greatly preferred because everyone, from whatever country, can understand it - while more complex issues of policy in a political campaign are frequently nation-specific and essentially "opaque" or incomprehensible to outsiders. For roughly the same reason, domestic media coverage in the popular press, such as USA Today, gives great weight to sports coverage over coverage of more complex, "serious" issues, such as foreign policy, healthcare, or immigration.

Nevertheless, the primary audiences of both The Chosun Daily and The Hankyoreh Daily are, of course, South Koreans. Thus, it is difficult to deny that South Korean papers were excessively concerned with horse-race issues rather than with substantive matters that actually impact South Koreans. Conversely, it might also be plausible to argue that reporting on horse-race issues to South Korean audiences was equally important since the manner in which the U.S would eventually handle the substantive issues of the FTA and North Korean relations largely depended on which candidate won the election. The study indicates that by apportioning less than $9 \%$ of their U.S. election coverage to national interest issues, both newspapers may have put too high a premium on horse-race reporting in their coverage.

\subsection{Partisan Difference between the Newspapers}

The study's findings show that the liberal Hankyoreh Daily put more emphasis on social justice issues, such as racial equality and the abolition of social discrimination, while the conservative Chosun Daily focused on human interest issues and more sensational topics, such as the candidates' career, gender, family, and fashion preferences.

The Hankyoreh Daily is considered to be a frontrunner in advocating for social justice and in abolishing social prejudices and inequality - more than any other daily newspaper in South Korea (Han, 2000; Song, 2007). Sang-woo Yang, the president of the Hankyoreh Media Group emphasized that The Hankyoreh Daily would make an effort to overcome "the oppression of political power and conciliation of capital power" (2011). The newspaper's status as a liberal media outlet in South Korea might be one of the factors that induced it to stress social justice issues in their coverage of the 2008 presidential election. On the other hand, The Chosun Daily's emphasis on human interest issues might have arisen from both its conservative viewpoint and its commercial interests. Human interest issues are particularly effective in catching readers' eyes, and their salience in The Chosun Daily's coverage can be understood in this context.

Our findings are meaningful in that they underscore how ideological viewpoints can shape news reporting as well as newsworthiness of the issues (topics) covered during an election season. The Hankyoreh Daily's advocacy for social justice might account for its emphasis on such matters in reporting on the U.S. elections, while The Chosun Daily's conservative viewpoint and commercialism might shed light on its emphasis on human interest stories.

It should also be mentioned that the prominence of human interest issues in The Chosun Daily's coverage may have originated from this newspaper's market-oriented approach. Indeed, as the largest circulation newspaper in South Korea, the conservative Chosun Daily might have viewed its audience primarily as "consumers." In contrast, the liberal Hankyoreh Daily may have been inclined to consider its audience as "citizens" and could therefore have advocated public interest and social causes, such as equality, in its coverage. In other words, the difference in the degree of market orientation between The Chosun Daily and The Hankyoreh Daily may have influenced the difference in the "issue salience" between these newspapers.

Beyond the ideological difference between the two newspapers, the findings show that both of them also stressed the qualifications of the candidates - especially those of Republican vice-presidential candidate Sarah Palin - as an important issue. This overemphasis on the question of Sarah Palin's qualifications appears to have been informed by our 
earlier contention about the uniqueness of the 2008 U.S. presidential election. It was an election in which issues of race (the first African American contender, Obama) and gender (the Republican vice presidential candidate, Palin, and Hillary Clinton, a strong contender for the Democratic Party's nomination) featured quite prominently. It needs to be noted that Palin's "qualifications" were also featured rather prominently in the coverage of U.S. media, which itself was the major source for South Korean newspapers' coverage.

One can reasonably argue that, in the context of American presidential politics, candidates Obama and Palin were "deviants", and their emergence was therefore of some political consequence. Never before had an African American contender become the standard-bearer of either major party. On the other hand, Sara Palin was a candidate who almost literally sprang up from "nowhere," personally chosen by the "maverick" Republican Party presidential nominee, John McCain. The "oddity" of both these candidates made news about them more attractive, as editors and news managers often refer to the "deviance-factor" in their selection of publishable news. As Shoemaker and Vos (2009) argued, deviance is the "news" item that contradicts what society deems to be normal.

\subsection{Usage of News Sources}

This study also examined how two Korean newspapers obtained their news stories. The findings show that the South Korean media's coverage of the U.S. presidential election falls within the general pattern of relying on the foreign media's reporting on its own domestic events. Indeed, $47.6 \%$ of the stories published by The Chosun Daily came from U.S. media reports while The Hankyoreh Daily's proportion was also high, at 41.5\%.

While we recognize there are financial difficulties involved in establishing news bureaus and in maintaining reporters all over the world, and that the subsequent practice of relying on other media organizations as sources of news is sometimes appropriate, South Korean newspaper's reliance on reports from the U.S. media as their major news sources is undeniably excessive. This reliance on American media as a news source could facilitate the transference of biases found in the initial stories to the secondary Korean readers, with the inherent possibility of misinforming them in the process.

This study found some degree of divergence between the two newspapers in their usage of other news sources. The conservative Chosun Daily used the candidates and other American politicians more frequently as their news sources for each news story than did The Hankyoreh Daily. By contrast, the ratio of Korean elites (scholars or politicians) as news sources in the progressive Hankyoreh Daily was higher (8.5\%) than that of the conservative Chosun Daily (1.1\%). In a similar way, The Hankyoreh Daily used American citizens as its news source twice as often as The Chosun Daily did (5.4\% vs. 2.7\%). Overall, American politicians were quoted more frequently in the news coverage of The Chosun Daily, whereas South Korean scholars were used more often as news sources in the stories by The Hankyoreh Daily.

It can be also inferred that the ideological orientations of the two newspapers might have influenced South Korean media's selection of the sources they utilized. The Chosun Daily relied heavily on the U.S. media and American politicians as its sources, which probably accounts for its emphasis on horse-race and human interest issues. However, The Hankyoreh Daily tried to present the voices of Korean citizens and elites in its coverage, reflecting its inclination to advocate social justice issues. Compared to The Chosun Daily, The Hankyoreh Daily generally presented their own perspectives - which could be considered to be contrary to those of the U.S. government and media. In the end, the liberal Hankyoreh Daily made more of an effort to present independent views of the U.S. election than did the conservative Chosun Daily.

\section{Conclusions}

This study investigated the relative weight given to horse-race or policy issues in the South Korean coverage of the 2008 U.S. election. It found that the coverage by both the liberal and conservative papers was dominated by horse-race news stories. Since audiences can learn a substantial amount from such horse-race coverage about both the issues and the personalities of the contenders for political office (Ladd \& Benson, 1992), it must be conceded that such coverage is not inconsequential; however, such issues tend, on the whole, to trivialize and reduce elections to just win-or-lose affairs (Gan, Teo, \& Detenber, 2005). Indeed, Fahey (2007) characterized the penchant to publish horse-race issues as a characteristic of reporters who shun the rigors of more serious news gathering and the writing of informed commentary.

Specifically, The Chosun Daily and The Hankyoreh Daily focused almost 50\% of their attention on horse-race issues, while they seemed to have been largely negligent in their reporting on the significant implications of the U.S. election. Despite the clear importance of the outcome of the U.S. election to South Korea's economy and national security, these two newspapers focused more of their attention on the publication of horse-race stories than on those dealing with substantive/policy issues. The Chosun Daily and The Hankyoreh Daily represent conservative and liberal voices in the South Korean media market, respectively. This suggests that a substantial portion of South Korean newspaper readers were exposed to election coverage that was largely focused on the question of which candidate was leading or losing in 
the polls at any given moment in the campaign. The substantial amount of horse-race coverage, rather than substantive issue coverage, by these two major newspapers raises questions about the credibility of their often-touted position as the "newspapers of record" and "authority" in South Korea.

This study examined how liberal and conservative Korean newspapers differed in their presentation of issues related to a major international news event that also happened to be crucial to Korean national interests. Specifically, it found that while South Korean newspapers concentrated their attention on "deviant" or "sensational" news items, the editors of these major newspapers might have lost sight of the importance of foreign and economic policy issues in their choice of what to publish about the U.S. election. One important and heuristic finding in this study is that the conservative Chosun Daily and the liberal Hankyoreh Daily differed in their choice of which issues were most salient; The Hankyoreh Daily highlighted social justice issues, whereas The Chosun Daily underscored human interest issues. These findings indicate that the ideological orientations of South Korean newspaper outlets played an important role in the divergence of issues accentuated by those newspaper media and, as a result, impeded the objective presentation of an international news event crucial to South Korea's national interests. In particular, it is notable that the differences in the election coverage between the liberal and conservative papers might have been determined by differences in the degree of market orientation and commercialism -that is, whether each newspaper primarily saw its readers as "consumers" or as "citizens."

\section{References}

Adebayo, D. (2008). World reacts to American election season. National Public Radio, September 8.

Anthony, B. C. (1980). Horse-race journalism: Reporting the polls in the 1976 presidential election. Public Opinion Quarterly, 44(4), 514-529. https://doi.org/10.1086/268620

Asher, H. (2007). Polling and the public: what every citizen should know. Washington, DC: CQ Press.

Bartels, L. M. (1988). Presidential primaries and the dynamics of public choice. Princeton, NJ: Princeton University Press.

Cappella, J. N., \& Jamieson, K. H. (1997). Spiral of cynicism: The press and the public good. New York: Oxford University Press.

Croteau, D. R., \& William, D. H. (2003). Media/society: industries, images, and audiences. Thousand Oaks, CA: Pine Forge Press.

Dimitrova, D. V., \& Stromback, J. (2011). Election news in Sweden and the United States: A comparative study of sources and media frames. Journalism, 13(5), 604-619. https://doi.org/10.1177/1464884911431546

Dimitrova, D. V., Kaid, L. L., Williams, A. P., \& Trammell, K. D. (2005). War on the Web: The immediate news framing of Gulf War II. Press/Politics, 10(1), 22-24. https://doi.org/10.1177/1081180X05275595

Eilders, C. (2006). News factors and news decisions: Theoretical and methodological advances in Germany. Communications, 31(1), 5-24. https://doi.org/10.1515/COMMUN.2006.002

Ellis, J. (2008, June 26). McCain and Obama on North Korea. New York Times. http://thecaucus.blogs.nytimes.com/2008/06/26/mccain-and-obama-on-north-korea/

Fahey, A. C. (2007). French and feminine: Hegemonic masculinity and the emasculation of John Kerry in the 2004 presidential race. Critical Studies in Media Communication, 24(2), 132-150. https://doi.org/10.1080/07393180701262743

Galtung, J., \& Ruge, M. H. (1965). The structure of foreign news. Journal of Peace Research, 2, 64-91. https://doi.org/10.1177/002234336500200104

Gan, T., Teo, J. L., \& Detenber, B. H. (2005). Framing the battle for the White House. Gazette: The International Journal for Communication Studies, 67(5), 441-467. https://doi.org/10.1177/0016549205056052

Golan, G. (2006). Inter-media agenda setting and global news coverage. Journalism Studies, 7(2), 323-333. https://doi.org/10.1080/14616700500533643

Graber, D. A. (2010). Mass media and American politics. Washington, D.C.: Congressional Quarterly Press.

Guzman, A. L. (2016). Evolution of news frames during the 2011 Egyptian revolution: Critical discourse analysis of Fox News's and CNN's framing of protesters, Mubarak, and the Muslim Brotherhood. Journalism \& Mass Communication Quarterly, 93(1), 80-98. https://doi.org/10.1177/1077699015606677

Ha, M. (2008, June 4) Obama, McCain differ on Korea policy. Korea Times. http://www.koreatimes.co.kr/www/news/nation/2008/06/116_25327.html 
Hafez, K. (2007). The Myth of media globalization. Cambridge, UK: Polity Press.

Han, D. (2000). The middle classes, ideological intention and resurrection of a progressive newspaper: A South Korean case. Gazette, 62(1), 61-74. https://doi.org/10.1177/0016549200062001005

Hester, A. L. (1973). Theoretical considerations in predicting volume and direction of international information flow. Gazette, 19, 239-247. https://doi.org/10.1177/001654927301900404

Holley, J. K. (1991). The press and political polling. In P. J. Lavrakas \& J. K. Holley (eds.), Polling and presidential election coverage. Newbury Park, CA: Sage Publications.

Iyengar, S., Norpoth, H., \& Hahn, K. S. (2004). Consumer demand for election news: The horserace sells. The Journal of Politics, 66(1), 157-175. https://doi.org/10.1046/j.1468-2508.2004.00146.x

Kang, M. (2005). The struggle for press freedom and emergence of unelected media power in South Korea. In J. N. Erni and S. K. Chua (eds.), Asian media studies: Politics of subjectivities. Malden, MA: Blackwell Publishing. https://doi.org/10.1002/9780470774281.ch5

Kim, H. S. (2002). Gatekeeping international news: An attitudinal profile of U.S. television journalists. Journal of Broadcasting \& Electronic Media, 46(3), 431-452. https://doi.org/10.1207/s15506878jobem4603_7

Kim, S. T., \& Kwon, H. N. (2009). Political communication in Korea: Looking back for the future. In L. Willnat and A. Aw (eds.), Political communication in Asia. New York: Routledge.

Kovach, B. (1980). A user's view of the polls. Public Opinion Quarterly, 44(4), 567-571. https://doi.org/10.1086/268623

Ladd, E. C., \& Benson, J. (1992). The growth of news polls in American politics. In T. E. Mann \& G. R. Orren (eds.), Media polls in American politics. Washington DC: The Brookings Institution.

Landis, J. R., \& Koch, G. G. (1977). The measurement of observer agreement for categorical data. Biometrics, 33, 159174. https://doi.org/10.2307/2529310

Lee, C. C., \& Yang, J. (1995). Foreign news and national interests: Comparing U.S. and Japanese coverage of a Chinese student movement. Gazette, 56(1), 1-18.

Lee, K., \& Lee, D. (2004, Nov.). Analysis of TV networks' U.S. election reporting. Korean Broadcasting Institute.

Lee, S., Kim, S., \& Wainwright, J. (2010). Mad cow militancy: Neoliberal hegemony and social resistance in South Korea. Political Geography, 21, 1-11. https://doi.org/10.1016/j.polgeo.2010.07.005

Lee, W. S. (2006). Ideological tendency and assessment of the government policy through reporting South-North Korea issue: Comparative analysis of editorials under Kim Young-Sam and Kim Dae-Jung administrations. Korean Journal of Communication and Information, 35, 329-411.

Lee, Y. (2005, Dec.). International news production system and correspondent system change. Newspaper and Broadcasting Journal, 76-80.

Lippmann, W. (1922). Public opinion. New York: Macmillan.

Mann, T. E., \& Orren, G. R. (1992). To poll or not to poll... and other questions. In T. E. Mann \& G. R. Orren (eds.), Media polls in American politics. Washington DC: The Brookings Institution.

Masonm, J. (2008, April 24). McCain hits Obama on diplomacy over North Korea. Reuters. http://www.reuters.com/article/topNews/idUSN1931827220080424

McCain, J. (2008, Sept. 20). McCain-Palin campaign web site.

McCombs, M. (2004). Setting the agenda. Cambridge, UK: Polity Press.

McCombs, M., \& Shaw, D. L. (1972). The agenda-setting function of mass media. Public Opinion Quarterly, 36(2), 176-187. https://doi.org/10.1086/267990

McCombs, M., \& Shaw, D. L. (1993). The evolution of agenda-setting research: Twenty-five years in the marketplace of ideas. Journal of Communication, 43(2), 58-67. https://doi.org/10.1111/j.1460-2466.1993.tb01262.x

Min, Y. (2000). Campaign agenda formation: The news media in the Korean congressional election of 2000. Asian Journal of Communication, 14(2), 192-304. https://doi.org/10.1080/0129298042000256767

Novais, R. A. (2007). National influences in foreign news: British and Portuguese press coverage of the Dili Massacre in East Timor. Gazette, 69(6), 553-573. https://doi.org/10.1177/1748048507082842

Ostgaard, E. (1965). Factors influencing the flow of news. Journal of Peace Research, 2, 39-63. 
https://doi.org/10.1177/002234336500200103

Park, R. B. (2008, Sept.) The 2008 media user survey. The Korea Press Foundation.

Patterson, T. E. (1993). Out of order. New York: Alfred A. Knopf.

Patterson, T. E. (2000). The United States: News in a free-market society. In R Gunther \& A Mughan (eds.), Democracy and the media. New York: Cambridge University Press. https://doi.org/10.1017/CBO9781139175289.007

Patterson, T. E. (2005). Of polls, mountains: U.S. journalists and their use of election surveys. Public Opinion Quarterly, 69(5), 716-724. https://doi.org/10.1093/poq/nfi065

Reinemann, C., \& Schulz, W. (2006). News decisions and news values. Communications, 31(1), 1-4. https://doi.org/10.1515/COMMUN.2006.001

Scammell, M. (2005). 'Four more years': How the UK press viewed the 2004 US presidential election. Journalism Studies, 6(2), 203-216. https://doi.org/10.1080/14616700500057338

Schwarz, A. (2006). The theory of newsworthiness applied to Mexico's press. How the news factors influence foreign news coverage in a transitional country. Communications, 31(1), 45-64. https://doi.org/10.1515/COMMUN.2006.004

Shoemaker, P. J., \& Reese, S. D. (2013). Mediating the Message in the $21^{s t}$ Century: A Media Sociology Perspective. New York: Routledge.

Shoemaker, P. J., \& Vos, T. P. (2009). The gatekeeping theory. New York, NY: Routledge.

Song, Y. (2007). Internet news media and issue development: A case study on the roles of independent online news services as agenda-builders for anti-US protests in South Korea. New Media \& Society, 9(1), 71-92. https://doi.org/10.1177/1461444807072222

Takeshita, T. (1997). Exploring the media's roles in defining reality: From issue-agenda-setting to attribute-agenda-setting. In M. McCombs, D. L. Shaw, \& D. Weaver (eds.), Communication and democracy: Exploring the intellectual frontiers in agenda-setting Theory. Mahwah, NJ: Erlbaum.

Tuchman, G. (1978). Making News. New York: Free Press.

Weaver, D. (2007). Thoughts on agenda setting, framing, and priming. Journal of Communication, 57(1), 142-147. https://doi.org/10.1111/j.1460-2466.2006.00333.x

Yang, S. (2011). Hankyoreh. The Hankyoreh Daily. http://company.hani.co.kr/

Zhao, X., \& Bleske, G. L. (1998). Horse-race polls and audience issue learning. The Harvard International Journal of Press/Politics, 3(4), 13-34. https://doi.org/10.1177/1081180X98003004004

\section{Copyrights}

Copyright for this article is retained by the author(s), with first publication rights granted to the journal.

This is an open-access article distributed under the terms and conditions of the Creative Commons Attribution license which permits unrestricted use, distribution, and reproduction in any medium, provided the original work is properly cited. 